\title{
Ecologically distinct pine species show differential root development after outplanting in response to nursery nutrient cultivation
}

\author{
Andrei Toca ${ }^{\mathrm{a}, \mathrm{c}}$, Juan A. Oliet ${ }^{\mathrm{b}}$, Pedro Villar-Salvador ${ }^{\mathrm{a}}$, Rodrigo A. Martínez Catalán ${ }^{\mathrm{b}}$, \\ Douglass F. Jacobs ${ }^{c, *}$ \\ ${ }^{a}$ Forest Ecology and Restoration Group, Departamento de Ciencias de la Vida, Apdo. 20, Universidad de Alcalá, E-28805 Alcalá de Henares, Madrid, Spain \\ ${ }^{\mathrm{b}}$ E.T.S. Ingeniería de Montes, Forestal y del Medio Natural, Departamento de Sistemas y Recursos Naturales, Universidad Politécnica de Madrid, 28040 Madrid, Spain \\ ${ }^{c}$ Department of Forestry and Natural Resources, Purdue University, West Lafayette, IN 47907, USA
}

\section{A R T I C L E I N F O}

\section{Keywords:}

Root growth dynamics

Nitrogen use efficiency

Rhizotron

Root architecture

Root plasticity

Specific root length

\begin{abstract}
A B S T R A C T
The capacity to rapidly expand root systems to increase soil foraging is key for the survival of tree seedlings in arid regions. Plants alter root growth dynamics and architecture in response to environmental changes and this plasticity in root development allows plants to maximize soil resource uptake. However, how variation in plant physiological status, such as nutrient content, affects root growth dynamics and architecture is poorly understood. We assessed how variation in seedling nutrient status affects root growth dynamics and architecture in three closely related, yet ecologically distinct pine species: Pinus nigra J.F. Arnold, Pinus pinaster Ait., and Pinus pinea L. Seedlings were cultivated under contrasting fertilization regimes to promote different levels of mineral nutrient content. Seedlings were then transplanted into rhizotrons to evaluate root growth dynamics and architecture over 10 weeks. Overall, increased seedling nutrient content enhanced root development, but species showed distinct root growth patterns and architecture. Pinus pinaster, which inhabits moderate climatic stress environments, showed the greatest root growth plasticity with variation in seedling nutrient content. In contrast, root development was less plastic in the pines adapted to more stressful environments, $P$. pinea, which occurs in sites with long and strong summer drought and $P$. nigra, which inhabits cold winter areas. High nutrient-content seedlings developed larger root systems by maintaining a greater number of growing roots rather than by increasing the elongation rate of individual roots, reflecting a strategy that likely improves soil foraging capacity. Nitrogen use efficiency for root growth (new root growth per unit of plant nitrogen content at planting) increased with increasing nutrient content in P. pinaster, yet the opposite effect occurred in the other two species. New roots of high nutrient-content seedlings had lower specific root length than low content seedlings in all species, suggesting that internal seedling nutrient status determines specific root length. The means by which increased seedling nutrient content affects root development after transplanting in pine species seems to be related to species ecology and stress resistance physiology. With a surplus of mineral nutrients during nursery cultivation, pine species from high stressful environments have low flexibility in modifying root development, while species from moderate climatic stress environments prioritize root development.
\end{abstract}

\section{Introduction}

Survival of forest tree seedlings in dry ecosystems depends on the capacity to rapidly expand root systems to increase soil foraging capacity (Canadell et al., 1996; Grossnickle, 2005). Root characteristics vary widely across plant species and these differences are due, in part, to adaptations to the environmental conditions of plant habitats (Pregitzer et al., 2002; Schenk and Jackson, 2002; Comas and Eissenstat, 2004; Andivia et al., 2019). For most growth forms, the absolute size of the root system and the shoot to root mass ratio tend to decrease along aridity gradients (Jackson et al., 1996; Schulze et al., 1996; Schenk and Jackson, 2002) while the rooting depth tends to increase (Canadell et al., 1996). Root systems are especially vulnerable to low soil temperature (Toca et al., 2018), which may have shaped the properties of root systems. In a global review, Freschet et al. (2017) reported that specific root length (SRL), a proxy of fine root proportion, was greater in plants from cold and temperate climatic areas than in plants from arid and tropical areas. Consequently, species segregation along aridity and temperature gradients could be driven by differences in root growth and architecture (Canadell et al., 1996; Schulze et al.,

\footnotetext{
* Corresponding author.

E-mail address: djacobs@purdue.edu (D.F. Jacobs).
} 
Table 1

Climatic characteristics of the provenances where seeds were collected and mean climatic characteristics of the species range in Spain. Provenance nomenclature follows Alía Miranda et al. (2009).

\begin{tabular}{|c|c|c|c|c|}
\hline \multicolumn{2}{|c|}{ Environmental conditions } & \multirow{2}{*}{$\begin{array}{l}\text { P. pinea } \\
\text { La Mancha, ES03 }\end{array}$} & \multirow{2}{*}{$\begin{array}{l}\text { P. pinaster } \\
\text { Cuenca, ES12 }\end{array}$} & \multirow{2}{*}{$\begin{array}{l}\text { P. nigra } \\
\text { Sistema Ibérico Meridional, ES07a }\end{array}$} \\
\hline Seed provenance & Provenance & & & \\
\hline & Altitude (m asl) & 675 & 1135 & 1515 \\
\hline & Mean annual temperature $\left({ }^{\circ} \mathrm{C}\right)$ & 14.2 & 12 & 10.4 \\
\hline & Mean temperature of the coldest month $\left({ }^{\circ} \mathrm{C}\right)$ & 0.7 & -1.5 & -3.2 \\
\hline & Annual rainfall (mm) & 397 & 540 & 894 \\
\hline \multirow[t]{4}{*}{ Species } & Mean annual temperature $\left({ }^{\circ} \mathrm{C}\right)$ & 13.6 & 12.0 & 11.2 \\
\hline & Mean temperature of the coldest month $\left({ }^{\circ} \mathrm{C}\right)$ & 0.9 & 0.5 & -1.6 \\
\hline & Annual rainfall (mm) & 587 & 884 & 743 \\
\hline & Summer rainfall (mm) & 74 & 102 & 133 \\
\hline
\end{tabular}

1996; Freschet et al., 2017).

The environmental conditions to which plants are exposed along their life also affects root properties by altering root growth dynamics, morphology and architecture. Specifically, soil water and nutrient availability, and temperature strongly affect root growth and architecture (Torreano and Morris, 1998; Sayer et al., 2005; Darychuk et al., 2012; Trubat et al., 2006). This plasticity of the root system allows plants to maximize soil resources uptake with environmental changes (Malamy, 2005; Padilla et al., 2007). Plant physiological status can also affect root development. For instance, the size of mineral nutrient storage (sensu Millard and Grelet, 2010) determines the absolute root growth of plants (Cuesta et al., 2010a; Millard and Grelet, 2010; VillarSalvador et al., 2015). Thus, fertilization during the cultivation period affects seedling mineral nutrient content, which in turn determines remobilization capacity (Millard and Grelet, 2010; Villar-Salvador et al., 2015) and photosynthesis rate (Evans, 1989; Oliet et al., 2013; Zhang et al., 2018). High photosynthesis and nutrient remobilization promotes high root growth (Villar-Salvador et al., 2012; Uscola et al., 2015), which is linked to higher field survival of large and nutrient-rich seedlings when compared to low nutrient content seedlings (VillarSalvador et al., 2012). However, unlike the vast literature on the effect of soil nutrient availability on root growth and architecture (Forde and Lorenzo, 2001; López-Bucio et al., 2003; Wang et al., 2013), the effects of internal nutrient status on root growth dynamics and architecture are poorly known for forest trees. Several studies suggest that both plant and soil nutrients may simultaneously regulate root architecture (Forde and Lorenzo, 2001; Forde, 2014). For instance, Zhang et al. (1999) showed that plant $\mathrm{NO}_{3}{ }^{-}$concentration modulated root branching in Arabidopsis thaliana L. (Heyn) by determining the timing of lateral root development. Similarly, Cuesta et al. (2010a) found that increasing seedling nitrogen $(\mathrm{N})$ content stimulated new root production and that tissue $\mathrm{N}$ content was more important than $\mathrm{N}$ concentration in modulating root growth in Pinus halepensis Mill. Because mineral nutrients such as $\mathrm{N}$, and carbohydrates are involved in both plant stress resistance (DeHayes et al., 1989; Saneoka et al., 2004; Villar-Salvador et al., 2013) and growth (Lambers et al., 2008), plants cannot maximize resource allocation into two main functions simultaneously (Herms and Mattson, 1992). Consequently, plants adapted to stressful environments usually have low plasticity in response to changes in resource availability (Chapin and Chapin, 1980; Valladares et al., 2007). Specifically, in environments where a nutrient conservative strategy is advantageous, plants usually show low plasticity to soil nutrient availability (Valladares et al., 2000; Power et al., 2019. Therefore, it can be hypothesized that the influence of variation in internal nutrient status on root growth and architecture can be constrained by the adaptive strategies of a given plant species. In this context, the study of root growth plasticity can be very useful to compare differences in the effect of nutrient content on root growth among ecologically distinct species (Valladares et al., 2006). As far as we know, however, no study has compared how variation in plant nutrient content affects the growth dynamics and architecture of new roots in forest tree species with contrasting ecology.

The objective of this study was to assess how variation in plant nutrient content after distinct nursery fertilization treatments affects early out-planting root growth dynamics and architecture in seedlings of three ecologically distinct pine species: Pinus pinea L., Pinus pinaster Ait. and Pinus nigra J.F. Arnold. These tree species are closely related, which reduces potential phylogenetic bias in assessing the relationship among root development, plant nutrient content and species ecology (Fitter and Stickland, 1991; Pregitzer et al., 2002). Using seedlings links the study with the natural recruitment process, which is crucial for understanding population dynamics, and also provides basic information for plant production in reforestation. The species employed are widespread across southern Europe but occupy distinct habitats and exhibit contrasting growth patterns (Barbero et al., 1998; Climent et al., 2011). Their distribution is segregated along an altitudinal gradient where aridity and temperature vary strongly (Table 1). Pinus pinea thrives at low-altitude semiarid sites under mild winter conditions and long, dry summers (Navarro Cerrillo et al., 2013). Pinus nigra mainly occurs in high mountain sites in southern Europe, where low temperature rather than summer drought is the main limiting abiotic factor for plant life (Barbero et al., 1998; Peñuelas et al., 2013). Finally, in Mediterranean-climate areas, $P$. pinaster is usually found at mid-elevation sites in habitats with moderate summer drought and cool winter conditions. The climatic niche of the latter pine species slightly overlaps with that of the other two species (Barbero et al., 1998).

We hypothesized that the effect of increasing nutrient content by fertilization on post-planting root growth dynamics and architecture will vary among ecologically different species. Species from moderate stress environments ( $P$. pinaster) will show large differences in root growth dynamics and architecture in response to variation in nutrient content. Conversely, species from high stress environments (i.e., drought for $P$. pinea and cold for $P$. nigra) will be less affected, as root growth is more constrained by their adaptations to stress. To test this hypothesis, we cultivated seedlings of these species under two contrasting fertilization regimes, to promote a gradient of organ nutrient content. Differences in nutrient content were achieved by supplying NPK fertilization at high and low rates during the growing season. Then we transplanted the seedlings into rhizotrons to compare root growth dynamics and architecture.

\section{Materials and methods}

\subsection{Plant material and experimental design}

Seeds of the three pines were collected from specific provenances of the Sistema Ibérico Meridional. Climate of these provenances, coordinates of seed sources and mean climatic characteristics in the species range in Spain are described in Table 1. To obtain the climatic characteristics we used distribution data for continental Spain from the third Spanish Forest Inventory, which analyzed the abundance of adults, saplings and seedlings of all woody species in plots distributed 
Table 2

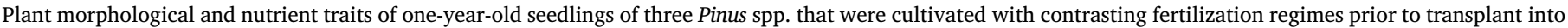
the rhizotrons. Data are means $\pm 1 \mathrm{SE}$.

\begin{tabular}{|c|c|c|c|c|c|c|}
\hline & \multicolumn{2}{|l|}{ Pinus pinea } & \multicolumn{2}{|l|}{ Pinus pinaster } & \multicolumn{2}{|l|}{ Pinus nigra } \\
\hline & Low & High & Low & High & Low & High \\
\hline $\mathrm{N}$ content $(\mathrm{g})$ & $37.3 \pm 4.4$ & $120.3 \pm 8.6$ & $28.2 \pm 2.6$ & $86.7 \pm 1.9$ & $22.4 \pm 1.1$ & $75.1 \pm 7.9$ \\
\hline $\mathrm{N}$ concentration $(\mathrm{mg} / \mathrm{g})$ & $6.7 \pm 0.7$ & $10.6 \pm 0.5$ & $6.3 \pm 0.0$ & $8.2 \pm 0.2$ & $7.4 \pm 0.2$ & $12.3 \pm 0.5$ \\
\hline $\mathrm{K}$ content $(\mathrm{g})$ & $28.7 \pm 1.0$ & $50.8 \pm 0.9$ & $22.2 \pm 2.5$ & $45.8 \pm 2.7$ & $12.6 \pm 1.2$ & $24.0 \pm 3.2$ \\
\hline $\mathrm{K}$ concentration $(\mathrm{mg} / \mathrm{g})$ & $5.2 \pm 0.3$ & $4.5 \pm 0.1$ & $5.0 \pm 0.2$ & $4.3 \pm 0.2$ & $4.2 \pm 0.4$ & $3.9 \pm 0.3$ \\
\hline P content $(\mathrm{g})$ & $8.6 \pm 0.4$ & $27.4 \pm 2.4$ & $7.1 \pm 0.5$ & $19.0 \pm 1.9$ & $4.1 \pm 0.2$ & $9.9 \pm 1.4$ \\
\hline $\mathrm{P}$ concentration $(\mathrm{mg} / \mathrm{g})$ & $1.5 \pm 0.1$ & $2.4 \pm 0.2$ & $1.6 \pm 0.0$ & $1.8 \pm 0.2$ & $1.3 \pm 0.0$ & $1.6 \pm 0.1$ \\
\hline Seedling mass $(\mathrm{g})$ & $5.6 \pm 0.1$ & $11.3 \pm 0.4$ & $4.5 \pm 0.4$ & $10.6 \pm 0.2$ & $3.0 \pm 0.1$ & $6.1 \pm 0.5$ \\
\hline Root/Shoot & $0.50 \pm 0.00$ & $0.33 \pm 0.00$ & $0.53 \pm 0.04$ & $0.34 \pm 0.01$ & $0.77 \pm 0.04$ & $0.61 \pm 0.08$ \\
\hline Initial root length (m) & $19.0 \pm 1.0$ & $23.6 \pm 1.4$ & $22.0 \pm 0.9$ & $19.3 \pm 2.5$ & $19.0 \pm 2.1$ & $19.5 \pm 2.7$ \\
\hline Fraction of fine roots $(\phi<1 \mathrm{~mm})$ & $0.68 \pm 0.01$ & $0.65 \pm 0.02$ & $0.63 \pm 0.04$ & $0.58 \pm 0.02$ & $0.62 \pm 0.05$ & $0.56 \pm 0.05$ \\
\hline
\end{tabular}

Table 3

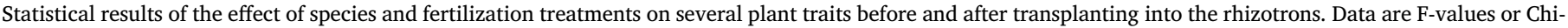
square (last four variables) and P-values in brackets. NUE stands for nitrogen use efficiency for root growth.

\begin{tabular}{|c|c|c|c|c|}
\hline & Traits & Species (Spp.) & Fertilization & Spp. $\times$ Fertil. \\
\hline \multirow[t]{10}{*}{ Pre-transplant } & Seedling $\mathrm{N}$ content & $17.2(<0.001)$ & $225(<0.001)$ & $4.6(0.032)$ \\
\hline & Seedling $\mathrm{N}$ concentration & $20.3(<0.001)$ & $115(<0.001)$ & $3.84(<0.001)$ \\
\hline & Seedling K content & $55.0(<0.001)$ & $121(<0.001)$ & $4.98(0.033)$ \\
\hline & Seedling K concentration & $4.37(0.034)$ & $5.31(0.041)$ & $0.34(0.326)$ \\
\hline & Seedling P content & $30.7(<0.001)$ & $113(<0.001)$ & $10.7(0.003)$ \\
\hline & Seedling P concentration & $9.93(0.003)$ & $23.7(<0.001)$ & $5.48(0.023)$ \\
\hline & Initial seedling mass & $72.3(<0.001)$ & $325(<0.001)$ & $12.5(0.002)$ \\
\hline & Initial seedling Root/Shoot & $27.8(<0.001)$ & $26.1(<0.001)$ & $0.13(0.121)$ \\
\hline & Initial root length & $0.647(0.498)$ & $0.459(0.475)$ & $2.19(0.126)$ \\
\hline & Total new root length & $2.93(0.072)$ & $65.4(<0.001)$ & $1.97(0.160)$ \\
\hline \multirow[t]{11}{*}{ Post-transplant } & Total new root mass & $8.28(<0.001)$ & $113(0.002)$ & $6.39(0.006)$ \\
\hline & Length of fine roots & $2.98(0.071)$ & $39.9(<0.001)$ & $1.24(0.307)$ \\
\hline & Length of coarse roots & $3.34(0.052)$ & $109(<0.001)$ & $3.34(0.052)$ \\
\hline & Percentage of fine roots & $2.19(0.126)$ & $1.75(0.210)$ & $0.09(0.075)$ \\
\hline & Specific root length & $0.80(0.461)$ & $23.1(<0.001)$ & $0.66(0.466)$ \\
\hline & NUE root length & $3.35(0.051)$ & $0.81(0.378)$ & $4.02(0.030)$ \\
\hline & NUE root mass & $8.56(<0.001)$ & $12.9(0.002)$ & $7.72(0.002)$ \\
\hline & Rooting depth & $51.6(<0.001)$ & $19.1(<0.001)$ & $7.3(0.026)$ \\
\hline & Number of elongating roots & $0.03(0.984)$ & $97.8(<0.001)$ & $29.8(<0.001)$ \\
\hline & Root system elongation rate & $1.5(0.466)$ & $160(<0.001)$ & $21.6(<0.001)$ \\
\hline & Elongation rate per root unit & $2.7(0.068)$ & $13.2(<0.001)$ & $2.4(0.091)$ \\
\hline
\end{tabular}

over forest ecosystems according to a $1-\mathrm{km}^{2}$ grid. For each studied species, we selected those plots classified as natural pine forests based on the Spanish Regions of Provenance (Ruiz-Benito et al., 2012) that had presence of seedlings. Mean values of climatic variables were calculated overlapping the selected plots on a climate map with $1-\mathrm{km}^{2}$ spatial resolution (Gonzalo, 2008). Seeds were sown on February 1, 2012 at the Centro Nacional de Recursos Genéticos Forestales "El Serranillo" (Central Spain, $40^{\circ} 40^{\prime} \mathrm{N}, 3^{\circ} 10^{\prime} \mathrm{W}, 650 \mathrm{~m}$ a.s.1.) into thermoformed plastic trays (Plasnor ${ }^{\circledR} 190 / 300-45$, Legazpi, Spain, 45 cells of $300 \mathrm{ml}$, cultivation density 283 plants $\mathrm{m}^{-2}$ ). Growing medium was sphagnum peat moss $\mathrm{pH}=4.7$, enriched with $16-10-20$ NPK fertilizer, $0.9 \mathrm{~kg} \cdot \mathrm{m}^{-3}$ (Kekkila ${ }^{\oplus}$ White $420 \mathrm{~F} 6$, Finland). Trays were kept in an unheated greenhouse during germination and emergence phases to avoid late spring frost damage.

On May 17, 2012 seedlings were transferred to the School of Forestry, Technological University of Madrid $\left(40^{\circ} 27^{\prime} \mathrm{N} ; 3^{\circ} 43^{\prime} \mathrm{W}, 664 \mathrm{~m}\right.$ a.s.1.) where the plants remained outdoors for the remainder of the experiment. Plants received two contrasting fertilization treatments designed to promote strong differences in nutrient content (Luis et al., 2009; Oliet et al., 2009): (1) High fertilization and 2) Low fertilization, where each plant was supplied with 150 and $20 \mathrm{mg}$ of $20 \mathrm{~N}-20 \mathrm{P}_{2} \mathrm{O}_{5}-20 \mathrm{~K}_{2} \mathrm{O}$ fertilizer (Scotts Co., Marysville, OH, USA), respectively, from May 22 to September 19, 2012. Fertilizer was applied weekly at a constant rate using a water-soluble fertilizer. Each fertilization treatment had three trays, resulting in a total of six trays per species. Trays were randomly allocated on the nursery bench, and their positions were rotated every 15 days. After the fertilization treatments were completed, seedlings were watered regularly until the beginning of the rhizotron experiment.

Root growth dynamics and root system architecture was assessed using rhizotrons, allowing non-invasive and non-destructive measurements of root architecture and growth dynamics over time (Huck and Taylor, 1982). Rhizotrons consisted of methacrylate tubes $1 \mathrm{~m}$ in length, $12 \mathrm{~cm}$ in exterior diameter, and a wall thickness of $0.6 \mathrm{~cm}$. The bottom end was closed with a perforated PVC lid to allow water drainage and prevent substrate loss. Five randomly selected seedlings per species and treatment were transplanted on April 27, 2013 into the rhizotrons placing the root plug against the transparent wall (one seedling in each rhizotron). The rhizotron was filled with a mix of 2:1 sieved and washed sand and perlite except the lowest $10 \mathrm{~cm}$ that was filled with gravel. Rhizotrons were inserted into a second opaque plastic tube, $1.1 \mathrm{~m}$ in length and $16 \mathrm{~cm}$ in diameter buried in the plot soil to maintain a similar temperature to the surrounding soil, while allowing for easy extraction. The opaque tube was buried with a $60^{\circ}$ inclination to force the roots to grow along the transparent wall (Cuesta et al., 2010a). A portion of the opaque tube and the rhizotron protruded above the soil $5-10 \mathrm{~cm}$. To prevent the heating of the top of the rhizotron, the protruding portion of the opaque tube was wrapped in an insulating white sheet. The experiment began with the substrate completely hydrated, mimicking wet soil in spring. During the experiment, 


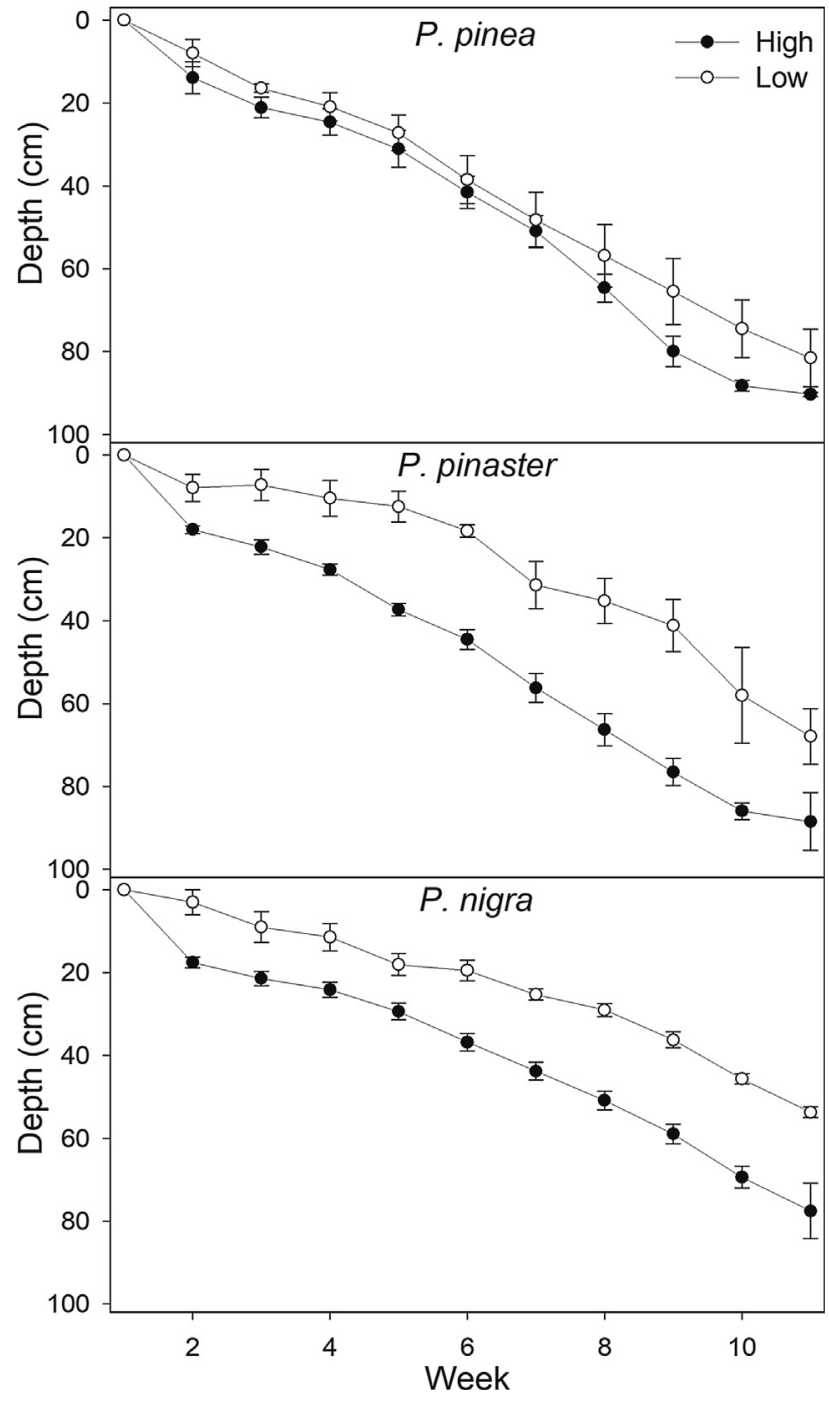

Fig. 1. Rooting depth over time in seedlings of three pine species that were transplanted into rhizotrons after being cultivated under two increasing fertilization regimes (Low, and high fertilization). Data means $\pm 1 \mathrm{SE}$.

seedlings were watered on three occasions with 0.51 tap water (May 8 and 15, and June 6). A (Scotts Co., Marysville, OH, USA) water-soluble fertilizer (NPK 20-20-20) was supplied at a low N concentration (7 mg/ L) with the irrigation on June 6, 2013. This low rate of fertilizer applied once during the experiment was to ensure that the essentially sterile media did not cause severe nutrient stress that might mask the expression of internal nutrient treatment effects.

\subsection{Initial plant nutrient status and morphology}

At the beginning of February, six seedlings per species and treatment (two per tray) were randomly harvested and frozen to $-20^{\circ} \mathrm{C}$ until processing to determine seedling $\mathrm{N}, \mathrm{P}$ and $\mathrm{K}$ concentration and content. Once defrosted, shoots were cut $5 \mathrm{~mm}$ below the cotyledon insertion point and separated into needles and stems, and roots were carefully washed from the growing medium with tap water. Samples were rinsed in distilled water for $3 \mathrm{~min}$ to remove any trace of nutrients on plant surfaces. Then, leaves, stems and roots were dried at $60{ }^{\circ} \mathrm{C}$ for $48 \mathrm{~h}$ and weighed to assess their mass. The leaves, stem and root of two seedlings were composited and ground in a ball mill (PM 100, Retsch, Haan, Germany) to make three composite samples per treatment (one per tray). Analysis of leaf, stem and root $\mathrm{N}$ and $\mathrm{P}$ concentration of these samples was done by the standard Kjeldahl method, while $\mathrm{K}$ concentration was determined using a perchloric acid extraction. Later all NPK concentrations were determined using an auto-analyzer (CFA SAN + +, Skalar, Breda, The Netherlands). N, P, and K content of organs was calculated as the product of organ mass and its respective mineral nutrient concentration. Plant N, P and K content was calculated as the sum of the root, stem and foliage $\mathrm{N}$ content. At the beginning of the rhizotron experiment, in April, another six seedlings per species and treatment were harvested in order to determine initial seedling mass, root to shoot ratio (root mass divided by shoot mass), $\mathrm{N}$ concentration (for later determination of $\mathrm{N}$ use efficiency for root growth) and root length. Initial root length was determined by scanning the root systems with EpsonScan v.304S 10000XL 3.4 (Epson, Tokyo, Japan) and the images analyzed with the software WinRhizo Pro 2007.d ${ }^{\circledR}$ (Regent Instruments, Canada) to obtain the total length.

\subsection{Root and shoot growth measurements}

Shoot height was measured weekly, beginning after planting until the end of the experiment (11 measurements). Shoot height was measured from a set point $5 \mathrm{~mm}$ below the cotyledon insertion scar to the apex of the bud (if present) in $P$. nigra and $P$. pinaster, and to the tip of the shoot in Pinus pinea, which did not develop a bud.

Root elongation measurements started 2 weeks after transplanting, when most of the seedlings had some visible roots growing against the rhizotron wall and were made weekly for 10 weeks. Roots were drawn on acetate sheets that were placed on the rhizotron wall in identical position on each measurement date. New roots were identified, and the new segments of existing roots were drawn with different colors each week. The minimum root length registered on sheets was $0.5 \mathrm{~cm}$ and roots that did not grow for more than 2 weeks were considered dead. Root growth dynamics was assessed through image analysis of the roots. Acetate sheets were scanned (Lide 120, Canon, Tokyo, Japan) and analyzed with the software SmartRoot (Lobet et al., 2011) to obtain the number of roots and the length of each root unit per week. This information was used to calculate root system elongation rate, rooting depth, number of growing roots, and total new root growth. The root system elongation rate was calculated as the sum of the root length increments of all individual roots between two measurement times. The number of growing roots was measured as the roots that showed elongation in the last 2 weeks. Rooting depth at a specific date was measured as the vertical distance from the bottom of the plug to the tip of the deepest root. Finally, the elongation rate per root unit was calculated as the total new root elongation rate divided by the number of growing roots.

On July 16, 2013, seedlings were extracted carefully from the rhizotrons by gently removing the growing medium with water. Plants were separated into needles, stem, old roots, and new roots, and washed with tap water. We considered new roots to be those that protruded out of the plug into the surrounding growing medium. After separating root fractions, plants were stored in the freezer at $-20^{\circ} \mathrm{C}$. Once defrosted, new roots were scanned with EpsonScan v.304S 10000XL 3.4 (Epson, Tokyo, Japan) and the images analyzed with the software WinRhizo Pro 2007. $\mathrm{d}^{\circledast}$ (Regent Instruments, Canada) to obtain the total length and diameter. Later, roots were differentiated into two categories: fine ( $\leq 1$ $\mathrm{mm}$ in diameter) and coarse ( $>1 \mathrm{~mm}$ in diameter) (King et al., 2002) in order to determine the length percentage of each cathergory. Samples were then dried at $60^{\circ} \mathrm{C}$ for $48 \mathrm{~h}$ and weighed to assess their mass. The specific root length (SRL) was calculated as the ratio between length and mass of new roots. Finally, $\mathrm{N}$ use efficiency for root growth (NUE) was calculated as the ratio between total new root length or total new root mass and the $\mathrm{N}$ content of the plants at time of transplanting to the rhizotrons.

A relative distance plasticity index (RDPI) for the root system was calculated following Valladares et al. (2006) using the R package Plasticity (Ameztegui, 2017) to estimate the phenotypic plasticity of root systems in response to variation in stored nutrients. Briefly, RDPI is 


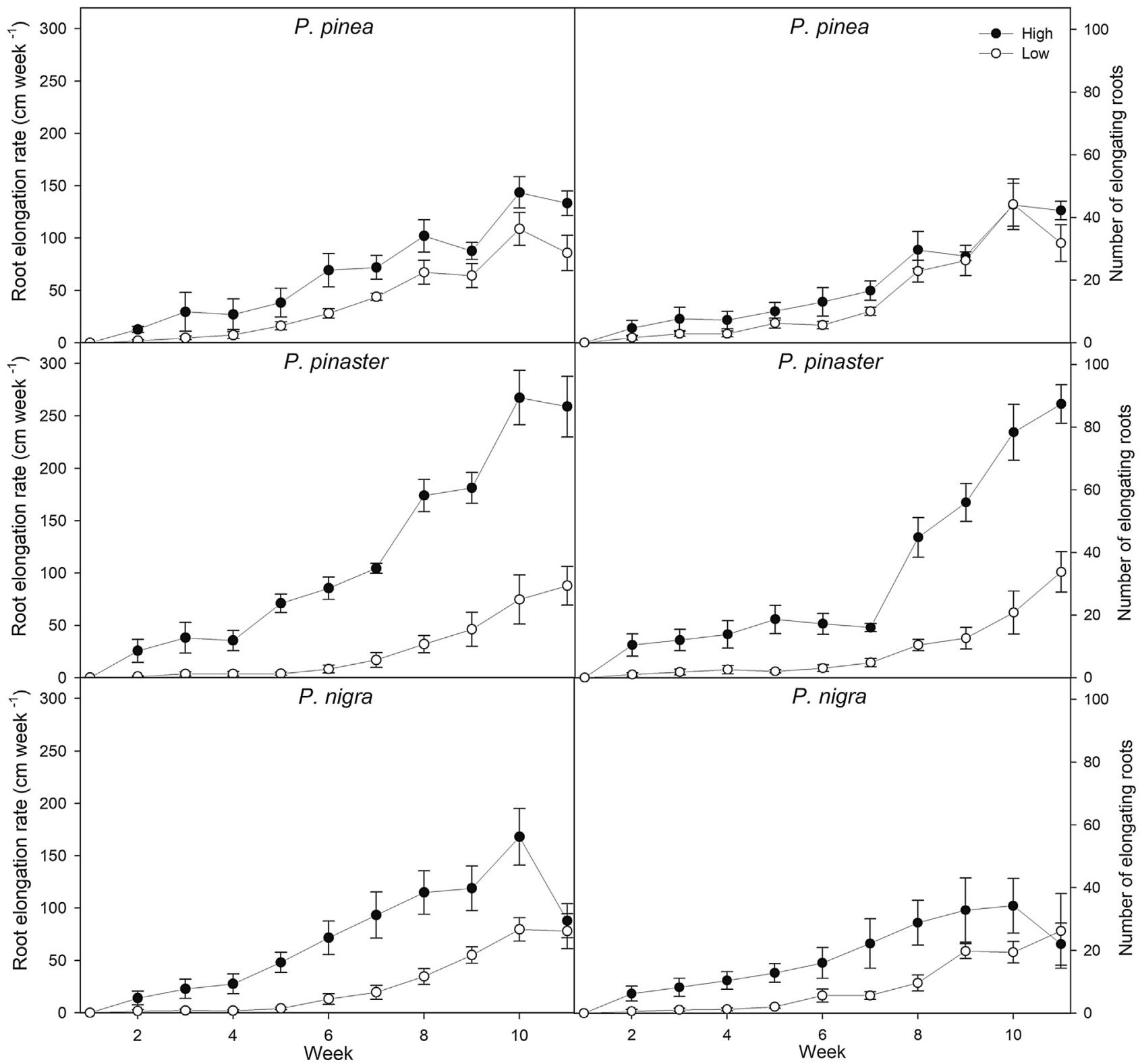

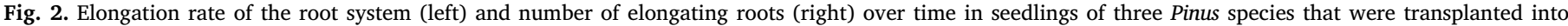
rhizotrons after being cultivated under two increasing fertilization regimes (low and high fertilization). Data are means \pm 1 SE.

calculated as the average of relative distances among all pairwise values of individuals from each species under the effect of an environmental gradient (fertilization in this case). The index ranges between 0 (no plasticity) to 1 (maximal plasticity) was calculated for seven root characteristics: Root system elongation rate, number of growing roots and depth in the tenth week of growth in the rhizotron, NUE, SRL, total new root length, and percentage of fine roots.

\subsection{Data analysis}

For $\mathrm{N}, \mathrm{P}$ and $\mathrm{K}$ content and concentration, seedling initial mass, root/shoot ratio, initial root length, total new root length and mass, percentage of fine roots length, SRL, NUE and RDPI, P-values were computed using F-tests as well as a randomization protocol that generated null distributions of variables and interactions by randomly reshuffling these data across species 10,000 times (Monte Carlo method, Crowley, 1992). For each of these subsamples we obtained the F-value of a two-way ANOVA analysis with species and treatments as main factors including interactions. The resulting 10,000 F-values were compared with the F-value (ANOVA) from the observed data. The Pvalue is the proportion of all data arrangements resulting in a test statistic at least as extreme in magnitude as the F-value from the observed data. P-values thus generated are expected to be more robust against potential biases in data (Crowley, 1992).

Data with repeated measurements (post-planting root growth dynamics) were analyzed via generalized linear mixed models. Species and fertilization treatments were included in the model as fixed effects and the seedling individual that was subjected to repeated measurements was included as a random effect. While rooting depth data followed a normal distribution, number of growing roots, root elongation rate and the elongation rate per root unit showed a gamma distribution. Data were analyzed with $\mathrm{R}$ version 3.3.0, R Core Team, 2016. Lme4 package (Bates et al., 2015) was used to perform the linear mixed effect models. Distributions were tested by Shapiro-Wilk and KolmogórovSmirnov tests. P-values of the models were obtained using the $\mathrm{R}$ package LmerTest (Kuznetsova et al., 2017). We considered results significant when P-values were $\leq 0.05$. Differences within species and treatments were determined via post hoc tests in $\mathrm{R}$ using a last-squares 


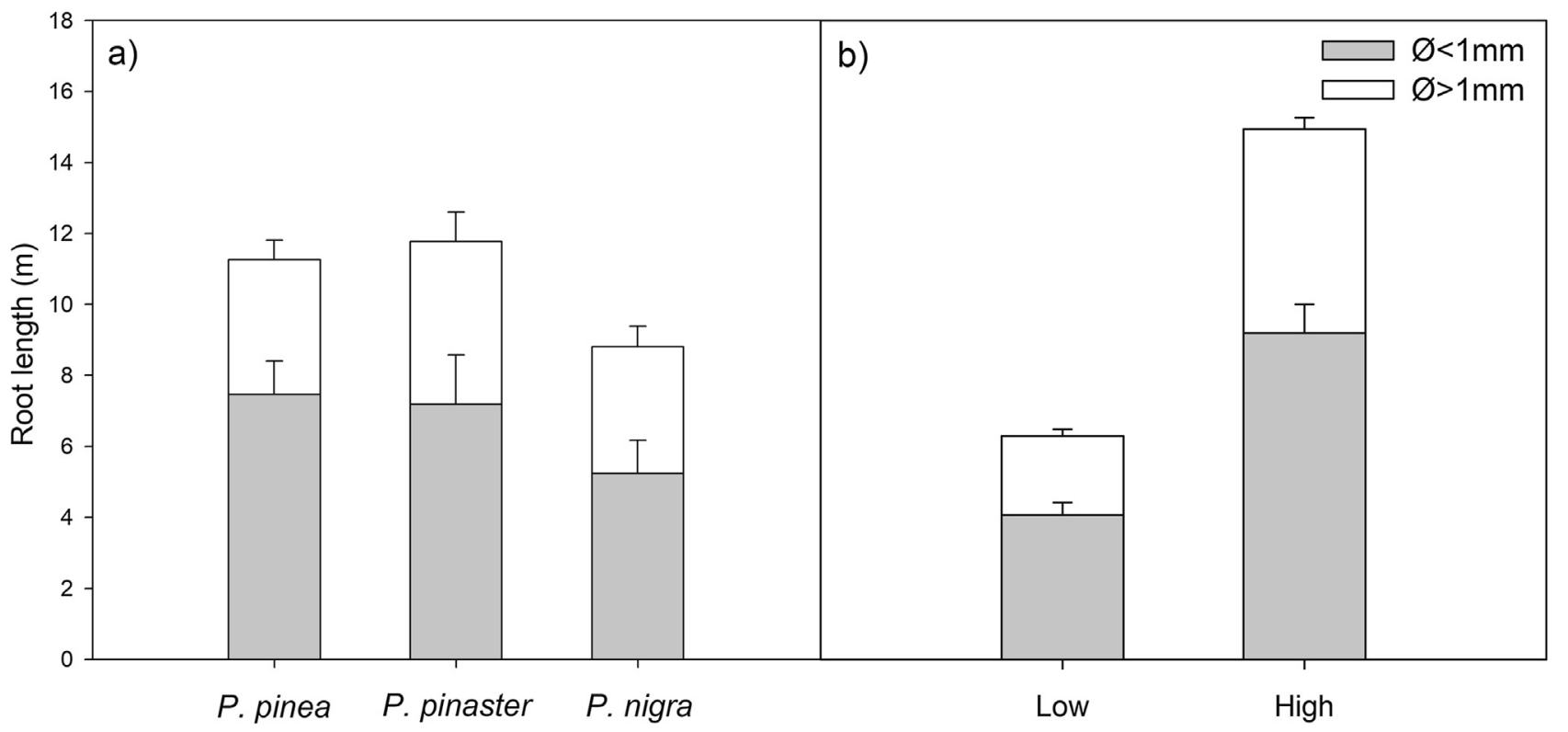

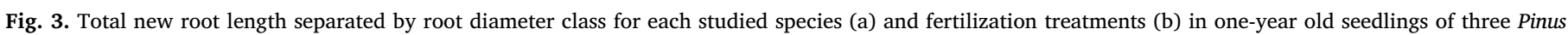

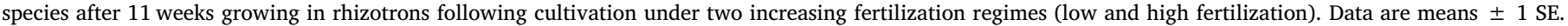

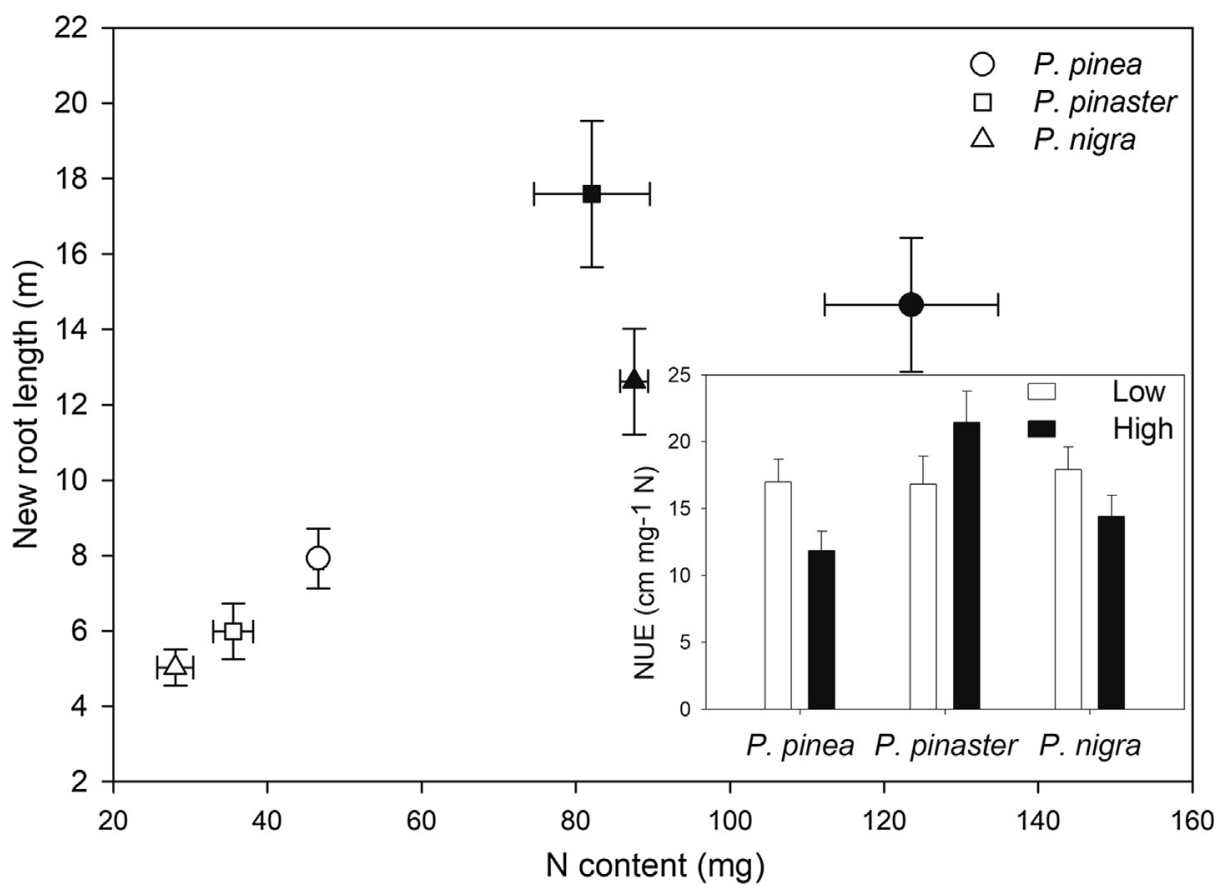

Fig. 4. New root length after 11 weeks growing in rhizotrons as a function of initial plant $\mathrm{N}$ content. One-year old seedlings of three pine species were cultivated under two increasing fertilization regimes (low and high fertilization). The inset figure represents the root length nitrogen use efficiency (NUE) by fertilization treatments and species. Data are means \pm 1 SE.

means analysis through lsmeans $\mathrm{R}$ package (Lenth, 2016). All analyses were performed in R software (R Foundation for Statistical Computing, Vienna, AT).

\section{Results}

\subsection{Initial plant morphology and nutrient status}

Overall, N, P and $\mathrm{K}$ content and concentration was highest among the high fertilized seedlings in all species (Table 2 and 3), except for $\mathrm{K}$ concentration which was highest in low fertilized plants. On average, $P$. pinaster and especially $P$. nigra seedlings had a lower nutrient content than $P$. pinea. However, the magnitude of the difference between low and high fertilized species varied for some nutrients (Species $\times$ Fertilization interactions, Table 3). High fertilized seedlings also had higher initial mass and lower root to shoot ratio, but their initial root length did not vary significantly.

\subsection{Root growth dynamics}

Species differed significantly in rooting depth over time, but the magnitude of the differences depended on fertilization treatment (Species $\times$ Fertilization interaction, Table 3 ). Low fertilized plants had less rooting depth than the high-fertilized plants in all species except for $P$. pinea, where fertilization treatments showed no differences (Fig. 1). On average, $P$. pinea had the deepest roots during the entire study period followed by $P$. pinaster and $P$. nigra, which showed no statistical differences. For instance, in the sixth week $P$. pinea roots were $30 \%$ deeper than $P$. pinaster roots and 51\% deeper than $P$. nigra roots (Fig. 1).

Elongation rate of the root system after planting steadily increased 


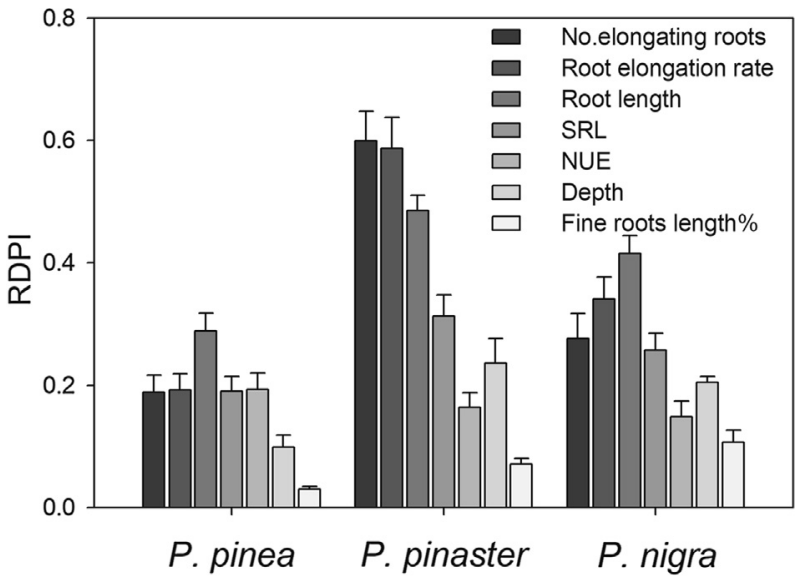

Fig. 5. Relative distance plasticity index (RDPI, Valladares et al., 2006) of several variables in one-year old seedlings of three Pinus species after 11 weeks growing in rhizotrons following cultivation under two increasing fertilization regimes (low and high fertilization). Indexes abbreviations were: SRL, specific root length; NUE, nitrogen use efficiency. All variables had significant statistical differences in RDPI among species.

over time, reaching maximum values during the tenth week in most cases and then slightly decreasing. This reduction in elongation rate coincided with the time that many plants reached the bottom of the rhizotrons (Fig. 2). In all species, high fertilized seedlings had higher root system elongation rate than the low-fertilized seedlings. However, the magnitude of this effect was greatest in $P$. pinaster, intermediate in $P$. nigra and lowest in $P$. pinea seedlings (Species $\times$ Fertilization interaction, Table 3, Fig. 2). Root system elongation rate of low-fertilized seedlings in $P$. pinaster and $P$. nigra was almost negligible for the first 5 weeks.

Results for the number of growing roots followed a similar pattern to results on elongation rate of the root system. The increase in the number of growing roots over time was gradual in $P$. nigra but abrupt in $P$. pinaster and $P$. pinea from week 7, increasing until at least week 10 (Fig. 2). After week 10, the number of growing roots declined in most treatments coinciding with the time that many plants reached the bottom of the rhizotron, similar to the effect observed for root system elongation rate. The effect of fertilization treatments prior to transplant on the number of growing roots followed similar patterns among species, although the magnitude of the effect differed (Species $\times$ Fertilization interaction, Table 3 ). High-fertilized plants had a greater number of growing roots than low-fertilized plants in all species. The number of growing roots in low fertilized $P$. pinaster and $P$. nigra seedlings was almost negligible for the first 5 weeks. The differences between the lowfertilized plants and the high-fertilized plants were greater in $P$. pinaster than in the other species.

Overall, elongation rate per root unit peaked between the 6th and 8th week and then decreased until the end of the experiment. The elongation rate per root unit was slightly lower in low fertilized plants, however did not differ among species (Table 3; Fig. A1).

\subsection{Total root and shoot development}

At the end of the experiment, the total length and mass of new roots varied among species (Table 3 and Fig. 3). Overall, total new root mass followed the order $P$. pinaster $>P$. pinea $>P$. nigra. Total and fine new root length was significantly lower in $P$. nigra than in the other two pine species, which were similar to each other, although the difference was marginally significant for both traits. Final length of coarse roots was higher in $P$. pinaster than in the other two species, which did not differ from each other. Total new root length and mass was also highly dependent on fertilization for all species (Table 3, Fig. 3). Total new root length of low-fertilized plants was less than the half of the root length measured in high-fertilized seedlings. Similarly, the length of fine and coarse roots of low-fertilized seedlings was significantly lower than that of high-fertilized plants. Total new root mass of high-fertilized plants was also significantly higher than low-fertilized plants across species (1.94 $\pm 0.17 \mathrm{~g}$ and $0.52 \pm 0.06 \mathrm{~g}$, respectively). However, species varied in the difference in new root mass between fertilization treatments (Species $\times$ Fertilization interaction in Table 3). $P$. pinaster showed the highest difference $(0.51 \pm 0.11 \mathrm{~g}$ and $2.61 \pm 0.18 \mathrm{~g}), P$. pinea showed the lowest difference $(0.68 \pm 0.13 \mathrm{~g}$ and $1.79 \pm 0.28 \mathrm{~g})$, while $P$. nigra showed intermediate differences $(0.36 \pm 0.06$ and $1.42 \pm 0.13$ ) for the low- and high-fertilized plants, respectively. The percentage of fine roots was similar among species $(66.8 \pm 0.0 \%$ for P. pinea, $61.5 \pm 0.0 \%$ for $P$. pinaster and $59 \pm 0.0 \%$ for $P$. nigra), and no differences occurred among fertilization treatments (Table 3, $(64.5 \pm 0.0 \%$ for Low and $60.5 \pm 0.0 \%$ for High)). Seedlings had very little shoot growth during the experiment. On average, over the 10 weeks, $P$. pinea, $P$. pinaster, and $P$. nigra grew $0.9,1.2$, and $2.8 \mathrm{~cm}$ in shoot height, respectively.

\subsection{Specific root length and root growth nitrogen use efficiency}

On average, low-fertilized seedlings had $60 \%$ higher SRL $\left(13.7 \pm 1.0 \mathrm{mg}^{-1}\right)$ than high-fertilized plants $\left(8.9 \pm 0.4 \mathrm{mg}^{-1}\right)$, with differences being significant. SRL was similar among species and was not affected by the interaction between species and $\mathrm{N}$ fertilization treatments (Table 3).

The length and mass of new roots at the end of the study increased with seedling nutrient content at planting in all species (Table 2, Figs. 3 and A2). Specifically, new root length and mass values in $P$. pinaster sharply increased with increasing $\mathrm{N}$ content compared to $P$. pinea and $P$. nigra. Consequently, species differed in NUE (both on a root length and a mass basis), but the differences depended on fertilization treatments (Species $\times$ Fertilization interaction, Table 3). While in high-fertilized $P$. pinaster seedlings showed higher NUE than low-fertilized seedlings, in $P$. pinea and $P$. nigra high-fertilized plants had lower (for root length) or similar (for root mass) NUE than low-fertilized plants (Figs. 4 and A2).

\subsection{Relative distance plasticity index}

Species varied significantly in their RDPI values for all the studied plant characteristics (Fig. 5 and Table A1). Overall, species RDPI differences followed the order $P$. pinaster $>P$. nigra $>P$. pinea.

\section{Discussion}

Overall, increasing plant nutrient content due to contrasting fertilization during cultivation (i) increased the elongation rate of the root system after transplanting and consequently final root system size and (ii) decreased SRL. Despite their close phylogenetic relatedness, pine species showed marked differences in the plasticity of root properties and in root growth NUE to variations in seedling nutrient content. In agreement with our hypothesis, species differences in root responses to variation in nutrient content seem to be linked to their ecology. Specifically, our results point to different strategies for using nutrient reserves for root growth depending on the cold and drought stress intensity to which they are exposed in their range. These nutrients, especially N and P, are critical for plant growth (Millard and Grelet, 2010) and stress resistance (DeHayes et al., 1989; Saneoka et al., 2004; Villar-Salvador et al., 2012). Therefore, observed specific differences might be driven by a trade-off between allocation of nutrients to growth and to stress resistance (Herms and Mattson, 1992). On one hand, $P$. pinaster, which occurs in sites with less drought and cold limitations than P. pinea and P. nigra, respectively (Table 1, Barbero et al., 1998), had the highest plasticity in root properties with variation in seedling nutrient content. Compared to the other pine species, it is possible that 
P. pinaster prioritizes the allocation of reserves to root growth rather than to stress resistance mechanisms. This could explain why NUE for root growth strongly increased with seedling nutrient content in $P$. pinaster, while it decreased in $P$. pinea and $P$. nigra. Moreover, Uscola et al. (2015) found that fast growth among woody species involves high dependence on stored nutrients. Consistent with this observation, the root system elongation rate of high nutrient content seedlings in $P$. pinaster was higher than that of $P$. pinea and $P$. nigra (Fig. 2), which could also be an indication that $P$. pinaster proportionally could rely more on reserves for root growth than the other pine species. On the other hand, $P$. pinea and $P$. nigra, the species that live in high stress habitats, had the lowest plasticity in root properties and root growth NUE in response to varying seedling nutrient content. This indicates that these species have a low flexibility in the use of surplus of stored nutrients for root growth. This low flexibility, along with low NUE, probably reflects a preference of nutrient allocation to other high demanding functions, such as stress resistance. Thus, $P$. pinea, which thrives in semiarid areas with mild winters developed the deepest root system (Fig. 1) yet showed the lowest plasticity in rooting depth and root elongation rate with variation in seedling nutrient content. In other words, $P$. pinea maximizes several root development traits independently of the amount of tissue nutrient content. Similar to findings in $P$. pinea, rooting depth in $P$. halepensis, which thrives in high water stress areas (Barbero et al., 1998; Puértolas et al., 2013), was also independent of seedling nutrient content (Cuesta et al., 2010a). Growth of deep and extensive root systems is a key trait for avoiding water stress (Grossnickle, 2005; Andivia et al., 2019) but has a high demand of nutrients (Pregitzer et al., 1997) that can, however, compensate the plant if it results in higher drought survival (Padilla and Pugnaire, 2007; Villar-Salvador et al., 2012). Finally, $P$. nigra, which inhabits the coldest but wettest areas, had notably lower root plasticity than $P$. pinaster but slightly higher or similar plasticity values than $P$. pinea (Fig. 5). It is possible that the low root plasticity in $P$. nigra compared to $P$. pinaster reflects a prioritization in the allocation of reserves to frost tolerance physiological mechanisms (DeHayes et al., 1989), such as the formation of antifreeze proteins (Atıc1 and Nalbantoğlu, 2003; Griffith and Yaish, 2004; Abril et al., 2011). Although our study hints to a link between species ecology and how variation in seedling nutrient content affects root growth, the limited number of species used (and provenances therein) constrains the generalization of our conclusions. Therefore, future studies should test our hypothesis with a higher number of ecologically contrasting species. Additionally, the results of this study can have operative implications for nursery production, suggesting that fertilization can affect seedling quality in different ways according to the ecology of the species that results in different nutrient use strategies.

Differences in the elongation rate and final size of root systems among fertilization treatments and species were more closely related to the number of elongating roots (and consequently to branching intensity) than to the elongation rate of individual roots. This result is supported by the following: increasing seedling nutrient content increased the number of growing roots in all species while there was little difference in the elongation rate per root unit among fertilization treatments and the temporal variation in the total root elongation rate mirrored the temporal pattern of the number of growing roots (Fig. 2). A similar root growth pattern was found in $P$. halepensis seedlings (Cuesta et al., 2010a), suggesting that pines show a common root elongation pattern based on the production of new root units that likely maximizes foraging effectiveness of root systems by exploring a higher soil volume (Fitter and Stickland, 1991).

The greater root growth in seedlings with higher nutrient content could be due to increased remobilization of reserves (Grelet et al., 2003; Uscola et al., 2015). For instance, $\mathrm{N}$ remobilization is a source driven process (Millard and Grelet, 2010) and consequently a higher amount of stored $\mathrm{N}$ is usually positively related to root growth (Fig. 3 and see Uscola et al., 2015; Villar-Salvador et al., 2015). In contrast to mineral nutrients, the relative importance of stored carbohydrates for new root growth seems to be low in conifers and new root growth relies mainly on currently fixed carbohydrates (van den Driessche, 1987; VillarSalvador et al., 2015). High-fertilized seedlings had greater leaf mass in all species (data not shown) and tissue $\mathrm{N}$ and $\mathrm{P}$ concentration (Table 2) than low fertilized plants, which indicates that the high root elongation rate of high-fertilized seedlings could also be due to differences in photosynthesis (Evans, 1989; Reich et al., 1998; Oliet et al., 2013; Zhang et al., 2018).

A major finding of this study is that plant nutrient status affects SRL. It is well known that low soil nutrients increases SRL (Ostonen et al., 2007; Wang et al., 2018). However, in our study all seedlings were transplanted into the same nutrient poor soil (sand and perlite) and nursery fertilization was terminated at least five months before the rhizotron experiment. Despite these growing conditions, low nutrient content seedlings had higher SRL than high nutrient content plants, which can be explained as a mechanism to increase or maintain foraging capacity with reduced costs. Other studies have shown that tissue nitrate concentration controls root branching and root hair elongation (Zhang et al., 1999; Forde and Lorenzo, 2001). However, in these studies, differences in tissue nitrate concentration and root growth were measured in plants growing under distinct fertilization rates, which precludes disentangling the influence of internal and external nutrients on SRL. Therefore, our study lends support to the hypothesis that internal nutrients has per se a strong control on SRL.

In contrast to SRL results, variation in seedling nutrient content did not affect the percentage of fine roots in any species. This suggests that variation in seedling nutrient content affected the production and elongation of fine and coarse roots in a similar way, but it likely affected root tissue density (Comas and Eissenstat, 2004; Kramer-Walter et al., 2016).

Results of this study have practical implications for forest restoration. As roots play a crucial role in seedling survival (Grossnickle, 2005; Padilla and Pugnaire, 2007) and seedling nutrient content strongly determines root development, our results highlight the importance of maximizing nutrient content in seedlings used in forest plantations (Salifu et al., 2009; Oliet et al., 2013), although this importance could vary with species ecology. This explains why many studies show that moderate to high nursery fertilized seedlings enhance field performance compared to low fertilized seedlings in seasonal dry climates such as in the Mediterranean (Cuesta et al., 2010b; Villar-Salvador et al., 2012).

\section{Conclusions}

Differences in seedling nutrient content induced by contrasting fertilization regimes during cultivation strongly affected root growth dynamics and architecture after transplanting. Overall, an increase in seedling nutrient content, as a result of prior nursery fertilization, enhanced root growth. Despite their close phylogenetic relatedness, however, pine species showed strong differences in root growth properties, which was linked to their ecology. Pinus pinaster, a species inhabiting moderate to low stress environments, showed higher root growth plasticity and NUE in response to changes in plant nutrient content than $P$. pinea and $P$. nigra, species inhabiting more stressful environments. We have also demonstrated that high nutrient content seedlings developed larger root systems by maintaining a greater number of growing roots rather than by increasing the elongation rate of individual roots, which can be interpreted as a strategy to maximize foraging efficiency. In addition, seedlings with low nutrient content had higher SRL than high nutrient content plants, indicating that internal nutrition status plays a significant role in SRL of root systems.

\section{Funding}

This research was supported by the projects AGL2011-24296 (ECOLPIN), CGL2014-53308-P (SERAVI) and by the network REMEDINAL 3 (S2013/MAE-2719) of the Community of Madrid. 


\section{Acknowledgements}

We thank the Forestry Research Center (CIFOR-INIA) for providing valuable assistance in root image analysis. We are grateful to Mike Szuter for the support with the data analysis and to Judit Maroto for the technical assistance.

\section{Appendix A. Supplementary material}

Supplementary data to this article can be found online at https:// doi.org/10.1016/j.foreco.2019.117562.

\section{References}

Abril, N., Gion, J., Kerner, R., et al., 2011. Phytochemistry proteomics research on forest trees, the most recalcitrant and orphan plant species. Phytochemistry 72, 1219-1242. https://doi.org/10.1016/j.phytochem.2011.01.005.

Alía Miranda, R., García del Barrio, J.M., Iglesias Sauce, S., Mancha Núñez, J.A., de Miguel y del Ángel, J., Nicolás Peragón, J.L., Pérez Martín, F., Sánchez de Ron, D., 2009. Regiones de procedencia de especies forestales en España. Organismo Autónomo de Parques Nacionales, Madrid, Spain.

Ameztegui, A., Plasticity: an R package to determine several plasticity indices. GitHub repository, 2017, < https://github.com/ameztegui/Plasticity > .

Andivia, E., Zuccarini, P., Grau, B., et al., 2019. Rooting big and deep rapidly: the ecological roots of pine species distribution in southern Europe. Trees 33 (1), 293-303. https://doi.org/10.1007/s00468-018-1777-x.

Atıcı, Ö., Nalbantoğlu, B., 2003. Antifreeze proteins in higher plants. Phytochemistry 64, 1187-1196. https://doi.org/10.1016/S0031-9422(03)00420-5.

Barbero, M., Loisel, R., Quézel, P., et al., 1998. Pines of the Mediterranean Basin. In: Richardson, D. (Ed.), Ecology and Biogeography of Pinus. Cambridge University Press, Cambridge, UK, pp. 153-170.

Bates, D., Maechler, M., Bolker, B., Walker, S., 2015. Fitting linear mixed-effects models using lme4. J. Stat. Softw. 67, 1-48. https://doi.org/10.18637/jss.v067.i01.

Canadell, J., Jackson, R.B., Ehleringer, J.B., et al., 1996. Maximum rooting depth of vegetation types at the global scale. Oecologia 108, 583-595. https://doi.org/10.1007/ BF00329030.

Chapin III, F.S., Chapin, F.S., 1980. The mineral nutrition of wild plants. Annu. Rev. Ecol. Syst. 11 (1), 233-260. https://doi.org/10.1146/annurev.es.11.110180.001313.

Climent, J., San-Martín, R., Chambel, M.R., Mutke, S., 2011. Ontogenetic differentiation between Mediterranean and Eurasian pines (sect. Pinus) at the seedling stage. Trees 25, 175-186. https://doi.org/10.1007/s00468-010-0496-8.

Comas, L.H., Eissenstat, D.M., 2004. Linking fine root traits to maximum potential growth rate among 11 mature temperate tree species. Funct. Ecol. 18, 388-397. https://doi. org/10.1111/j.0269-8463.2004.00835.x.

Crowley, P.H., 1992. Resampling methods for data analysis in ecology and evolution. Annu. Rev. 23, 405-447. https://doi.org/10.1146/annurev.es.23.110192.002201.

Cuesta, B., Vega, J., Villar-Salvador, P., Rey-Benayas, J.M., 2010a. Root growth dynamics of Aleppo pine (Pinus halepensis Mill.) seedlings in relation to shoot elongation, plant size and tissue nitrogen concentration. Trees 24, 899-908. https://doi.org/10.1007/ s00468-010-0459-0.

Cuesta, B., Villar-Salvador, P., Puértolas, J., et al., 2010b. Why do large, nitrogen rich seedlings better resist stressful transplanting conditions? A physiological analysis in two functionally contrasting Mediterranean forest species. For. Ecol. Manage. 260, 71-78. https://doi.org/10.1016/j.foreco.2010.04.002.

Darychuk, N., Hawkins, B.J., Stoehr, M., 2012. Trade-offs between growth and cold and drought hardiness in submaritime Douglas-fir. Can. J. For. Res. 42, 1530-1541. https://doi.org/10.1139/x2012-092.

DeHayes, D.H., Ingle, M.A., Waite, C.E., 1989. Nitrogen fertilization enhances cold tolerance of red spruce seedlings. Can J For Res 19, 1037-1043. https://doi.org/10. 1139/x89-158.

Evans, J.R., 1989. Photosynthesis and nitrogen relationships in leaves of C3 plants. Oecologia 78, 9-19. https://doi.org/10.1007/BF00377192.

Fitter, A.H., Stickland, T.R., 1991. Architectural analysis of plant root systems 2. Influence of nutrient supply on architecture in contrasting plant species. New Phytol. 118, 383-389. https://doi.org/10.1111/j.1469-8137.1991.tb00019.x.

Forde, B.G., 2014. Nitrogen signalling pathways shaping root system architecture: an update. Curr. Opin. Plant. Biol. 21, 30-36. https://doi.org/10.1016/j.pbi.2014.06. 004.

Forde, B.G., Lorenzo, H., 2001. The nutritional control of root development. Plant Soil 232, 51-68. https://doi.org/10.1023/A:1010329902165.

Freschet, G.T., Valverde-Barrantes, O.J., Tucker, C.M., et al., 2017. Climate, soil and plant functional types as drivers of global fine-root trait variation. J. Ecol. 105, 1182-1196. https://doi.org/10.1111/1365-2745.12769.

Gonzalo, J., 2008. Diagnosis fitoclimática de la España peninsular. Actualización y análisis geoestadístico aplicado. Universidad Politécnica de Madrid.

Grelet, G.-A., Alexander, I.J., Millard, P., Proe, M.F., 2003. Does morphology or the size of the internal nitrogen store determine how Vaccinium spp. respond to spring nitrogen supply? Funct. Ecol. 17, 690-699. https://doi.org/10.1046/j.1365-2435.2003. 00776.x.

Griffith, M., Yaish, M.W.F., 2004. Antifreeze proteins in overwintering plants: a tale of two activities. Trends Plant Sci. 9, 399-405. https://doi.org/10.1016/j.tplants.2004.
06.007.

Grossnickle, S.C., 2005. Importance of root growth in overcoming planting stress. New For. 30, 273-294. https://doi.org/10.1007/s11056-004-8303-2.

Herms, D.A., Mattson, W.J., 1992. The dilemma of plants: to grow or defend. Q. Rev. Biol. 67, 283-335. https://doi.org/10.1086/417659.

Huck, M.G., Taylor, H.M., 1982. The rhizotron as a tool for root research. In: Advances in Agronomypp. 1-35. https://doi.org/10.1016/S0065-2113(08)60320-X.

Jackson, R.B., Canadell, J., Ehleringer, J.R., et al., 1996. A global analysis of root distributions for terrestrial biomes. Oecologia 108, 389-411. https://doi.org/10.1007/ BF00333714.

King, J.S., Albaugh, T.J., Allen, H.L., et al., 2002. Below-ground carbon input to soil is controlled by nutrient availability and fine root dynamics in loblolly pine. New Phytol. 154, 389-398. https://doi.org/10.1046/j.1469-8137.2002.00393.x.

Kramer-Walter, K.R., Bellingham, P.J., Millar, T.R., et al., 2016. Root traits are multidimensional: specific root length is independent from root tissue density and the plant economic spectrum. J. Ecol. 104, 1299-1310. https://doi.org/10.1111/13652745.12562.

Kuznetsova, A., Brockhoff, P.B., Christensen, R.H.B., 2017. lmer test package: tests in linear mixed effects models. J Stat Softw 82, 1-26. https://doi.org/10.18637/jss. v082.i13.

Lambers, H., Chapin, F.S., Pons, L., 2008. Plant physiological ecology, II. Springer.

Lenth, R.V., 2016. Least-squares means: the r package lsmeans. J. Stat. Softw. 69, 1-33 https://doi.org/10.18637/jss.v069.i01.

Lobet, G., Pagès, L., Draye, X., 2011. A novel image-analysis toolbox enabling quantitative analysis of root system architecture. Plant. Physiol. 157, 29-39. https://doi.org/ 10.1104/pp.111.179895.

López-Bucio, J., Cruz-Ramírez, A., Herrera-Estrella, L., 2003. The role of nutrient availability in regulating root architecture. Curr. Opin. Plant. Biol. 6, 280-287. https:// doi.org/10.1016/S1369-5266(03)00035-9.

Luis, V.C., Puértolas, J., Climent, J., et al., 2009. Nursery fertilization enhances survival and physiological status in Canary Island pine (Pinus canariensis) seedlings planted in a semiarid environment. Eur. J. For. Res. 128, 221-229. https://doi.org/10.1007/ s10342-009-0257-7.

Malamy, J.E., 2005. Intrinsic and environmental response pathways that regulate root system architecture. Plant, Cell Environ. 28, 67-77. https://doi.org/10.1111/j.13653040.2005.01306.x.

Millard, P., Grelet, G., 2010. Nitrogen storage and remobilization by trees: ecophysiological relevance in a changing world. Tree Physiol. 30, 1083-1095. https://doi.org/ 10.1093/treephys/tpq042.

Navarro Cerrillo, R.M., Sánchez Lancha, A., Arroyo Sauces, M., Plaza Arregui, L., Mallofret Carrera, E., Lara Gómez, M., Monge, R., 2013. Pinus pinea L. In: Pemán, J. Navarro-Cerrillo, R.M., Nicolás, J.L., Prada, M.A., Serrada, R. (Eds.), Producción y Manejo de Semillas y Plantas Forestales, Tomo II. Organismo Autónomo Parques Nacionales, Madrid, Spain, pp. 928-959.

Oliet, J.A., Puértolas, J., Planelles, R., Jacobs, D.F., 2013. Nutrient loading of forest tree seedlings to promote stress resistance and field performance: a Mediterranean perspective. New For. 44, 649-669. https://doi.org/10.1007/s11056-013-9382-8.

Oliet, J.A., Planelles, R., Artero, F., et al., 2009. Field performance of Pinus halepensis planted in Mediterranean arid conditions: relative influence of seedling morphology and mineral nutrition. New For. 37, 313-331. https://doi.org/10.1007/s11056-0089126-3.

Ostonen, I., Püttsepp, Ü., Biel, C., et al., 2007. Specific root length as an indicator of environmental change. Plant Biosyst. - An Int. J. Deal with all Asp Plant Biol. 141, 426-442. https://doi.org/10.1080/11263500701626069.

Padilla, F.M., Pugnaire, F.I., 2007. Rooting depth and soil moisture control Mediterranean woody seedling survival during drought. Funct. Ecol. 21, 489-495. https://doi.org/ 10.1111/j.1365-2435.2007.01267.x.

Padilla, F.M., Miranda, J.D.D., Pugnaire, F.I., 2007. Early root growth plasticity in seedlings of three Mediterranean woody species. Plant Soil 296, 103-113. https:// doi.org/10.1007/s11104-007-9294-5.

Peñuelas, J.L., Nicolás Peragón, J.L., Benito Matias, L.F., 2013. Pinus nigra subsp. salzmannii (Dunal) Franco. In: Pemán, J., Navarro-Cerrillo, R.M., Nicolás, J.L., Prada, M.A., Serrada, R. (Eds.), Producción y manejo de semillas y plantas forestales. Tomo II. Organismo Autónomo Parques Nacionales, Madrid, Spain, pp. 881-927.

Power, S.C., Verboom, G.A., Bond, W.J., Cramer, M.D., 2019. Does a trade-off between trait plasticity and resource conservatism contribute to the maintenance of alternate stable states? New Phytol. 1809-1819. https://doi.org/10.1111/nph.15981.

Pregitzer, K.S., DeForest, J.L., Burton, A.J., et al., 2002. Fine root architecture of nine north American trees. Ecol. Monogr. 72, 293-309. https://doi.org/10.1890/0012 9615(2002) 072[0293:FRAONN]2.0.CO;2.

Pregitzer, K.S., Kubiske, M.E., Yu, C.K., Hendrick, R.L., 1997. Relationships among root branch order, carbon, and nitrogen in four temperate species. Oecologia 111, 302-308. https://doi.org/10.1007/s004420050239.

Puértolas, J., Prada, M.A., Climent, J., Oliet, J., Del Campo, García A., 2013. Pinus halepensis Mill. In: Pemán, J., Navarro-Cerrillo, R.M., Nicolás, J.L., Prada, M.A., Serrada, R. (Eds.), Producción y Manejo de Semillas y Plantas Forestales. Tomo II. Organismo Autónomo Parques Nacionales, Madrid, Spain, pp. 855-880.

Reich, P.B., Walters, M.B., Tjoelker, M.G., et al., 1998. Photosynthesis and respiration rates depend on leaf and root morphology and nitrogen concentration in nine boreal tree species differing in relative growth rate. Funct. Ecol. 12, 395-405. https://doi. org/10.1046/j.1365-2435.1998.00209.x.

Ruiz-Benito, P., Gómez-Aparicio, L., Zavala, M.A., 2012. Large-scale assessment of regeneration and diversity in Mediterranean planted pine forests along ecological gradients. Divers. Distrib. 18, 1092-1106. https://doi.org/10.1111/j.1472-4642 2012.00901.x

Salifu, K.F., Jacobs, D.F., Birge, Z.K.D., 2009. Nursery nitrogen loading improves field 
performance of bareroot oak seedlings planted on abandoned mine lands. Restor Ecol. 17, 339-349. https://doi.org/10.1111/j.1526-100X.2008.00373.x.

Saneoka, H., Moghaieb, R.E.A., Premachandra, G.S., Fujita, K., 2004. Nitrogen nutrition and water stress effects on cell membrane stability and leaf water relations in Agrostis palustris Huds. Environ. Exp. Bot. 52, 131-138. https://doi.org/10.1016/j.envexpbot. 2004.01.011.

Sayer, M.A.S., Brissette, J.C., Barnett, J.P., 2005. Root growth and hydraulic conductivity of southern pine seedlings in response to soil temperature and water availability after planting. New For. 30, 253-272. https://doi.org/10.1007/s11056-005-7481-x.

Schenk, H.J., Jackson, R.B., 2002. Rooting depths, lateral root spreads and belowground/above-ground allometries of plants in water-limited ecosystems. J. Ecol. 90, 480-494. https://doi.org/10.1046/j.1365-2745.2002.00682.x.

Schulze, E.-D., Mooney, H.A., Sala, O.E., et al., 1996. Rooting depth, water availability, and vegetation cover along an aridity gradient in Patagonia. Oecologia 108, 503-511. https://doi.org/10.1007/BF00333727.

Toca, A., Oliet, J.A., Villar-Salvador, P., et al,, 2018. Species ecology determines the role of nitrogen nutrition in the frost tolerance of pine seedlings. Tree Physiol. 38, 96-108. https://doi.org/10.1093/treephys/tpx165.

Torreano, S.J., Morris, L.A., 1998. Loblolly pine root growth and distribution under water stress. Soil Sci. Soc. Am. J. 62, 818-827. https://doi.org/10.2136/sssaj1998. $03615995006200030040 x$

Trubat, R., Cortina, J., Vilagrosa, A., 2006. Plant morphology and root hydraulics are altered by nutrient deficiency in Pistacia lentiscus (L.). Trees 20, 334-339. https://doi. org/10.1007/s00468-005-0045-z.

Uscola, M., Villar-Salvador, P., Gross, P., Maillard, P., 2015. Fast growth involves high dependence on stored resources in seedlings of Mediterranean evergreen trees. Ann. Bot. 115, 1001-1013. https://doi.org/10.1093/aob/mcv019.

Valladares, F., Martinez-Ferri, E., Balaguer, L., Perez-Corona, E., Manrique, E., 2000. Low leaf-level response to light and nutrients in Mediterranean evergreen oaks: A conservative resource-use strategy? New Phytol. 148, 79-91. https://doi.org/10.1046/j. 1469-8137.2000.00737.x.
Valladares, F., Sanchez-Gomez, D., Zavala, M.A., 2006. Quantitative estimation of phenotypic plasticity: bridging the gap between the evolutionary concept and its ecological applications. J. Ecol. 94, 1103-1116. https://doi.org/10.1111/j.1365-2745. 2006.01176.x.

Valladares, F., Gianoli, E., Gómez, J.M., 2007. Ecological limits to plant phenotypic plasticity. New Phytol. 176, 749-763.

Van den Driessche, R., 1987. Importance of current photosynthate to new root growth in planted conifer seedlings. J. Chem. Inf. Model. 17, 776-782. https://doi.org/10. 1139/x87-124.

Villar-Salvador, P., Uscola, M., Jacobs, D.F., 2015. The role of stored carbohydrates and nitrogen in the growth and stress tolerance of planted forest trees. New For. 46 813-839. https://doi.org/10.1007/s11056-015-9499-z.

Villar-Salvador, P., Penuelas, J.L., Jacobs, D.F., 2013. Nitrogen nutrition and drought hardening exert opposite effects on the stress tolerance of Pinus pinea L. seedlings. Tree Physiol. 33, 221-232. https://doi.org/10.1093/treephys/tps133.

Villar-Salvador, P., Puértolas, J., Cuesta, B., et al., 2012. Increase in size and nitrogen concentration enhances seedling survival in Mediterranean plantations. Insights from an ecophysiological conceptual model of plant survival. New For. 43, 755-770. https://doi.org/10.1007/s11056-012-9328-6.

Wang, G., Fahey, T.J., Xue, S., Liu, F., 2013. Root morphology and architecture respond to $\mathrm{N}$ addition in Pinus tabuliformis, west China. Oecologia 171, 583-590. https://doi. org/10.1007/s00442-012-2441-6.

Wang, W., Wang, Y., Hoch, G., et al., 2018. Linkage of root morphology to anatomy with increasing nitrogen availability in six temperate tree species. Plant Soil 425 , 189-200. https://doi.org/10.1007/s11104-018-3563-3.

Zhang, H., Jennings, A., Barlow, P.W., Forde, B.G., 1999. Dual pathways for regulation of root branching by nitrate. Proc. Natl. Acad. Sci. 96, 6529-6534. https://doi.org/10. 1073/pnas.96.11.6529.

Zhang, H., Li, W., Adams, H.D., et al., 2018. Responses of woody plant functional traits to nitrogen addition: a meta-analysis of leaf economics, gas exchange, and hydraulic traits. Front. Plant Sci. 9, 1-10. https://doi.org/10.3389/fpls.2018.00683. 